\title{
The remedial response to bribes and secret commissions in a fiduciary relationship
}

\author{
Peter DeVonshire*
}

Faculty of Law, University of Auckland

W hen a fiduciary receives a bribe to subvert his or her duties, what remedies are available to the principal to recover the bribe or its exchange product and any derivative profits? The classic authority of Lister \& Co $v$ Stubbs $^{1}$ provides a restrictive answer. The principal is confined to a personal claim against the errant fiduciary. ${ }^{2}$ On strict proprietary reasoning, the bribe money is deemed the property of the recipient and although he or she is liable to account for this sum, the resultant obligation is only a debt. This has profound consequences. The viability of a claim in personam is dependent on the defendant's solvency. If, as is not uncommon, the defendant is improvident in his or her own financial affairs as well as dishonest, the principal's claim will be reduced to that of an unsecured creditor. Conversely, the assertion of a proprietary claim confers priority over the res, which does not form part of the insolvent defendant's estate. If the property has been transferred or substituted for other assets, the principal may follow the asset in specie or trace in equity. ${ }^{3}$ Moreover, a proprietary claim enables the principal to capture any increase in value of the property or its exchange product, together with any profits it has generated.

In Attorney General for Hong Kong $v$ Reid, ${ }^{4}$ the Privy Council rejected the reasoning of Lister $v$ Stubbs and held that bribe money and its proceeds were held on constructive trust for the principal. The principal therefore acquires beneficial ownership of the bribe and can trace its value into identifiable substitutes. In a notable development, in Sinclair Investments (UK) Ltd v Versailles Trade Finance $L t d,{ }^{5}$ the Court of Appeal declined to follow Reid and argued that proprietary relief is misconceived unless the fiduciary has taken an asset that is beneficially the property of the principal or has acquired property by exploiting an opportunity or right belonging to the principal. ${ }^{6}$

* A version of this article was presented to the Restitution Section of the Society of Legal Scholars at the Annual Conference, University of Bristol, September 2012. I am grateful to Professor Peter Watts QC for his helpful comments on a previous draft.

1 (1890) 45 Ch D 1 (CA).

2 This may take the form of an action for money had and received or for recovery of an equitable debt. Alternative claims in tort and contract are not considered here.

3 In both cases the claim is defeated if the property passes to a bona fide purchaser for value (Foskett $v$ McKeown [2001] 1 AC 102 (HL) 127).

4 [1994] 1 AC 324 (PC).

5 [2011] EWCA Civ 347, [2012] Ch 453.

6 Ibid [88]. 
This paper will explore the implications of these distinctions against a common set of facts. There are many contexts for bribery, from abuse of public office to betrayal of an employer's interests. For present purposes bribery will be considered in relation to an employee or an agent who is responsible for acquiring property or services on behalf of his or her employer or principal, or who deals with third parties who seek to purchase property, goods or services from the employer or principal.

\section{Elements of the modern debate}

Lister \& Co v Stubbs concerned a purchasing agent, Stubbs, who received bribes from a trade supplier to induce him to breach his duty to his employer and place purchase contracts with the briber. ${ }^{7}$ When his actions were discovered, Stubbs' employer applied for an interlocutory injunction to restrain him from disposing of certain freehold properties and investments that represented the proceeds of the bribes. To advance this claim, the employer sought to establish an interest in the funds. At first instance, ${ }^{8}$ the application was dismissed. Stubbs' conduct was plainly a breach of duty but the bribe money had not originated from the employer and was therefore not clothed with a trust in the hands of the employee. ${ }^{\text {? }}$

The judgment was upheld by the Court of Appeal, ${ }^{10}$ which held that receipt of a bribe by an employee merely gives rise to a debtor-creditor relationship between employer and employee. In this setting, breach of fiduciary duty failed to kindle a trustee-beneficiary relationship. This reflected a strict proprietary analysis of the parties' interests: the bribe money was deemed the property of the dishonest employee and although he was accountable for this to his employer, the resultant liability was only a debt. To rule otherwise was to confound ownership with obligation. ${ }^{11}$ The employer was therefore unable to assert a proprietary claim and could not trace the bribe money into substituted assets. ${ }^{12}$

7 The plaintiff was engaged in silk-spinning and dyeing. The defendant, Stubbs, was a foreman entrusted with purchasing dyeing materials. In consideration for placing large orders with the firm of Varley \& Co, Stubbs received secret commissions.

8 (1890) 45 Ch D 1.

9 The conclusion would be different if money was given by the employer to the employee for payment of goods ordered on the employer's behalf: ibid 4.

10 The court comprised a strong bench of Cotton, Lindley and Bowen LJJ.

11 (1890) 45 Ch D 1, 15 per Lindley LJ.

12 The rejection of the constructive trust argument created the anomaly that a rogue who accepted a bribe was in a more favourable position than an 'honest' fiduciary who made an unauthorised profit (see, for example, Boardman v Phipps [1967] 2 AC 46 (HL)). The preponderant academic view was that the analysis of Lister $v$ Stubbs had been outstripped by modern equitable doctrines. In particular Lister had become increasingly difficult to reconcile with equity's enforcement of fiduciary obligations and the expansive application of constructive trusts. See R Goff and G Jones, The Law of Restitution (3rd edn Sweet \& Maxwell 1986) 656-57; J Martin (ed), Hanbury and Maudsley's Modern Equity (13th edn Stevens \& Sons 1989) 627-28; D J Hayton and O R Marshall, Cases and Commentary on the Law of Trusts (8th edn Stevens \& Sons 1986) 444-46; Jacobs' Law of Trusts in Australia (5th edn Butterworths 1986) 297-99; R P Meagher, W M C Gummow and J R F Lehane, Equity: Doctrines and Remedies (3rd edn Butterworths 1992) 153-56; A J Oakley, Constructive Trusts (2nd edn Sweet \& Maxwell 1987) 55-58; P Pettit, Equity and the Law of Trusts (6th edn Butterworths 1989) 152. Contra: P Birks, An Introduction to the Law of Restitution (revd edn Clarendon Press 1989) 388-89; A A Burrows, The Law of Restitution (Butterworths 1993) 409ff; R Goode, 'Ownership and Obligation in Commercial Transactions' (1987) 103 LQR 433. 
Despite reservations, ${ }^{13}$ Lister $v$ Stubbs remained good law ${ }^{14}$ until a century later, when the fundamental distinction between legal and equitable duty was robustly swept aside by the Privy Council in Attorney General for Hong Kong $v$ Reid. ${ }^{15}$ In this case, the defendant, Reid, held senior positions in the legal department of the government of Hong Kong, where he was responsible for the prosecution of major commercial frauds. During this time he accepted bribes for obstructing the prosecution of certain offences. In 1990 he was convicted under the Prevention of Bribery Ordinance and ordered to pay the Crown $H K \$ 12.4$ million, which sum was presumed to be derived from bribes. Part of the funds were used by Reid to acquire three freehold properties in New Zealand. The Attorney General for Hong Kong lodged caveats against these properties on the grounds that they represented the proceeds of bribes received in breach of Reid's fiduciary duty to his employer, the Crown, for whom they were held on constructive trust. Proceedings were subsequently commenced to prevent the caveats from lapsing.

It was held at first instance ${ }^{16}$ that, on the authority of Lister $v$ Stubbs, Reid was accountable for the bribes on a debtor-creditor basis only. He was not a constructive trustee of the monies or their substitutes and accordingly the Crown had no proprietary interest in the New Zealand properties. This was affirmed by the Court of Appeal of New Zealand. ${ }^{17}$ Richardson J, delivering the judgment of the Court, accepted that Lister v Stubbs was a settled authority which had been properly applied in this case.

On further appeal, the Privy Council rejected Lister v Stubbs, in a doctrinaire judgment that affirmed equity's antipathy towards corrupt fiduciaries. Delivering the advice of the Board, Lord Templeman noted that Reid, as a servant of the Crown, stood in a fiduciary relationship to his employer. ${ }^{18}$ It was accepted that at law the bribe money belonged to the recipient, Reid. ${ }^{19}$ However, equity views illicit gains by a fiduciary with repugnance. Acting in personam, equity insists that it is unconscionable for the fiduciary to retain any benefit resulting from a breach of duty.

From this, the Board invoked a key principle which effectively overreaches a Lister $v$ Stubbs analysis. As equity regards as done that which ought to be done, as soon as the bribe money was received by the fiduciary, the money or its proceeds was held on constructive trust for the principal. ${ }^{20}$ Reid was effectively treated as lacking status or capacity in equity to hold the bribe. In language which suggested that the delinquent fiduciary was incapable ab initio of acquiring any beneficial interest in the money, it was said: ${ }^{21}$

13 DPC Estates Pty Ltd v Grey [1974] 1 NSWLR 443 at 470-71; Queensland Mines v Hudson [1976] ACLC 28,658, 28,708; Sumitomo Bank Ltd v Thabir [1993] 1 SLR 735 (HC).

14 Although concerns were voiced as to the Lister v Stubbs principle, the decision was generally followed. See Powell \& Thomas v Evan Jones \& Co [1905] 1 KB 11; Attorney-General's Reference (No 1 of 1985) [1986] 1 QB 491; Daly v Sydney Stock Exchange (1986) 160 CLR 371; Islamic Republic of Iran Shipping Lines v Denby [1987] 1 Lloyd's Rep 367.

15 [1994] 1 AC 324 (PC).

16 High Court, Hamilton, 13 September 1991, Penlington J.

17 [1992] 2 NZLR 385 (CA).

18 A fiduciary relationship is readily inferred in such circumstances. See, for example, Attorney-General v Goddard (1929) 98 LJKB 743 (policeman) and Reading v Attorney-General [1951] AC 507 (HL) (army sergeant).

19 As the board bluntly acknowledged: 'Money paid to the false fiduciary belongs to him.' ([1994] 1 AC 324 at 331).

20 In line with cases such as Keech v Sandford (1726) Sel Cas t King 61, 25 ER 223, and Boardman v Phipps [1967] 2 AC 46 (HL), it was irrelevant that the principal could not have obtained that particular benefit. The principal's inability to pursue a gain is even more demonstrable as regards bribes, where the gain is unlawful.

21 [1994] 1 AC 324, 331 per Lord Templeman, delivering the advice of the Privy Council. 
As soon as the bribe was received it should have been paid or transferred instanter to the person who suffered from the breach of duty. Equity considers as done that which ought to have been done. As soon as the bribe was received, whether in cash or in kind, the false fiduciary held the bribe on a constructive trust for the person injured.

Attorney General for Hong Kong $v$ Reid has generally held sway in English jurisprudence,22 although it has not been universally followed. ${ }^{23}$ An abiding concern is the elision of fundamental understandings as to the nature of personal and proprietary obligations. As Professor Birks has pointed out, proprietary restitution is only justified where the claim is founded on a proprietary base, as where the fiduciary misapplies the principal's property. In contrast, bribe money derives from a third party, not the principal. ${ }^{24}$

In a major development, the Court of Appeal in Sinclair Investments (UK) Ltd v Versailles Trade Finance $L t d{ }^{25}$ declined to follow Reid and stated, as a general proposition, ${ }^{26}$ that a fiduciary will only be personally accountable for a profit obtained in breach of fiduciary duty. Sinclair arose from a complex fraudulent scheme involving inter-company dealings. Mr Cushnie, a director of T Ltd, fraudulently applied T Ltd's funds to artificially inflate the value of V Ltd, a company in which he held shares. Subsequently, Cushnie sold the shares in V Ltd for $\AA^{28.69}$ million.

In civil proceedings, ${ }^{27}$ the claimant, as assignee of the interests of $\mathrm{T} \mathrm{Ltd}$, asserted an equitable proprietary interest in the proceeds of the shares sold by Cushnie in breach of his fiduciary duties as director of T Ltd. Although Cushnie was personally accountable for the profit, the claimant sought a constructive trust over the gains and their substitutes to obtain priority over all claimants except a bona fide purchaser for value without notice. The problem from the claimant's perspective was that, while T Ltd and its resources were instrumental in the unlawful scheme, the gain was achieved by disposing of shares in an independent entity.

Lewison $\mathrm{J}$ (as he then was) ${ }^{28}$ found that Cushnie had acquired the shares in V Ltd before T Ltd had been incorporated and before he had assumed any fiduciary duties to the latter. T Ltd could not establish any proprietary interest in the shares and the only claim by T Ltd was in relation to the gains made on their sale as a result of share manipulation involving T Ltd. This gave rise to a personal claim only. ${ }^{29} \mathrm{~T} \mathrm{Ltd}$ could not therefore assert a proprietary interest in the proceeds of the shares or pursue such claim against traceable proceeds. ${ }^{30}$

Delivering the judgment of the Court of Appeal, Lord Neuberger of Abbotsbury MR, ${ }^{31}$ explained that, while no bribes or secret commissions were alleged, the relevant principles derive from this area of law. Accordingly, if a claimant beneficially owns

22 For example, Ocular Sciences Ltd v Aspect Vision Care Ltd [1997] RPC 289 (Ch) 412-13; Daraydan Holdings Ltd v Solland International Ltd [2004] EWHC 622 (Ch), [2005] Ch 119 [86]; Ultraframe (UK) Ltd v Fielding [2005] EWHC 1634 (Ch) [1490]. Cf Halifax Building Society v Thomas [1996] Ch 217, 229 (CA); Attorney General v Blake [1997] Ch 84, 96.

23 Reid has also been mired by conflicting views as to the precedent of a Privy Council decision in relation to domestic courts, including the Court of Appeal.

24 Birks (n 12) 386.

25 [2011] EWCA Civ 347, [2012] Ch 453.

26 See below for discussion of cases where a proprietary claim can be sustained.

27 Cushnie's actions also led to a criminal prosecution resulting in conviction and a term of imprisonment.

28 [2010] EWHC 1614 (Ch). For earlier proceedings, see [2007] EWHC 915 (Ch) (Rimer J).

29 Ibid [81].

$30 \mathrm{~T}$ Ltd was successful in a separate claim in respect of moneys from $\mathrm{T}$ Ltd which had passed to another company and became mixed with the latter's funds. Here, the Court of Appeal upheld the finding that T Ltd was entitled to trace the funds and assert a proprietary claim against third parties.

31 Richards and Hughes LJJ concurring. 
a bribe received by a fiduciary, it follows that TPL's [T Ltd] proprietary claim to the proceeds of sale of the shares [in V Ltd] must succeed'. ${ }^{32}$ After detailed analysis, the Court of Appeal upheld the finding below that Cushnie was personally accountable to T Ltd, but the proceeds were not held on constructive trust. The claimant's proprietary argument was soundly rejected. ${ }^{33}$

At the core of his rejection of Reid, Lord Neuberger MR distinguished between the exploitation by a fiduciary of property or opportunities subject to fiduciary obligations, and the wrongful exploitation of a fiduciary position, resulting in unauthorised gains: ${ }^{34}$

In cases where a fiduciary takes for himself an asset which, if he chose to take, he was under a duty to take for the beneficiary, it is easy to see why the asset should be treated as the property of the beneficiary. However, a bribe paid to a fiduciary could not possibly be said to be an asset which the fiduciary was under a duty to take for the beneficiary. There can thus be said to be a fundamental distinction between (i) a fiduciary enriching himself by depriving a claimant of an asset and (ii) a fiduciary enriching himself by doing a wrong to the claimant.

It was only in the first category that an asset should be treated as the principal's property, to be held on constructive trust. Receipt of a bribe fell in the second category. Such conduct was manifestly wrongful, but there was no duty to obtain the bribe for the principal. Similarly, on the facts of Sinclair, the defendant was under no duty to obtain, on behalf of the claimant, the profit from the sale of his shares. The claimant accordingly had no proprietary basis for a constructive trust. His Lordship elaborated that a beneficiary is entitled to an equitable account in respect of any asset acquired by a fiduciary in breach of his or her duty, but a proprietary claim could not arise: 35

unless the asset or money is or has been beneficially the property of the beneficiary or the trustee acquired the asset or money by taking advantage of an opportunity or right which was properly that of the beneficiary.

Sinclair's analysis arouses concerns as to the apparent exemption of one of the more serious breaches of fiduciary duty from the customary rigour of equitable doctrine. ${ }^{36}$ This has attracted the rebuke that: ${ }^{37}$

To exclude the bribed fiduciary from the deterrent effect of the constructive trust is ... to make it unavailable in the very situations where deterrence is likely to be the most needed. Bribery at its most naked breeds the crudest form of fiduciary infidelity. To privilege the dishonest fiduciary in this way is to create an incentive which should not be tolerated.

The restriction of proprietary relief to an 'opportunity or right which was properly that of the beneficiary' is contentious, in the context of bribes and more widely. ${ }^{38}$ It is not

32 [2011] EWCA Civ 347, [2012] Ch 453 [56].

33 As a matter of authority, it was held that Reid was inconsistent with earlier Court of Appeal decisions (particularly Lister \& Co v Stubbs (1890) 45 Ch D 1), and the House of Lords (Tyrell v Bank of London (1862) 10 HL Cas 26). Lord Neuberger MR stated that the Court of Appeal was not required to follow the Privy Council decision of Reid in preference to judgments of the Court of Appeal unless there are domestic authorities which indicate that the latter were per incuriam or of doubtful reliability. Absent powerful reasons to the contrary, the Court of Appeal should follow its own previous decisions ([2011] EWCA Civ 347, [2012] Ch 453 [73]).

34 [2011] EWCA Civ 347, [2012] Ch 453 [80].

35 Ibid [88].

36 Compare with FHR European Ventures LLP v Mankarious [2013] EWCA Civ 17, [2014] Ch 1. See n 43 below. See further P Devonshire, Account of Profits (Thomson Reuters 2013) 50-58.

37 Grimaldi v Chameleon Mining NL (No 2) [2012] FCAFC 6 [576].

38 See Cadogan Petroleum plc v Tolley [2011] EWHC 2286 (Ch) [27]; Page v Hewetts Solicitors [2011] EWHC 2449 (Ch). 
immediately apparent where the principle begins and ends. It would probably comprehend the interception of specific property that was, or realistically could have been, enjoyed by the principal. More problematic would be the 'corporate opportunity' class of cases where a director, without authority, diverts potential customers from the company, to his or her own competing business. ${ }^{39}$ In some cases the opportunity may have been causally remote and, by extension, uncertainty may surround the value of the actual opportunity. It is questionable whether proprietary relief is appropriate in such cases, where there is no apparent proprietary base and the claimant's interest cannot be readily quantified. At the same time, there is support for the contrary view, namely that a maturing business opportunity should be regarded as the property of the company. In some cases this has been described as a species of trust property, potentially exposing the faithless director to proprietary relief in the form of a constructive trust over the fruits of the exploited opportunity. ${ }^{40}$ Arguably, Sinclair's endorsement of proprietary relief where a fiduciary takes advantage of an opportunity provides impetus for this reasoning.

More broadly, Sinclair raises uncertainties regarding constructive trusts. The traditional vehicle for equitable proprietary relief is, perhaps unwittingly, threatened by a side wind, if Lord Neuberger MR's prescription in relation to secret commissions has general application. Absent a proprietary base, the constructive trust would be curtailed in proceedings for breach of fiduciary duty, unless the principal can establish an interest or right which is sufficiently proximate to the fiduciary's acquisition. ${ }^{41}$ If the remedy is circumscribed in this way, then the fiduciary who enriches him or herself by committing a wrong $^{42}$ to the principal is personally accountable in equity, but beyond the reach of proprietary relief. It seems that the balance struck in Sinclair threatens to inhibit the effective enforcement of equity's most hallowed principles, such as the profit and conflict rules. ${ }^{43}$

\section{Receipts and subtractions}

In some instances a bribe or secret commission is treated as a receipt by the fiduciary on behalf of the principal. ${ }^{44}$ Such funds in the hands of the false fiduciary, as agent or

39 For example, CMS Dolphin Ltd v Simonet [2001] 2 BCLC 704 (Ch); Harris v Digital Pulse Pty Ltd [2003] NSWCA 10, (2003) 56 NSWLR 298.

40 Cook v Deeks [1916] AC 554 (HL) 564 (Lord Buckmaster LC); Brown v Bennett [1999] BCC 525 (CA) 531 (Morritt LJ); CMS Dolphin Ltd v Simonet [2001] 2 BCLC 704 (Ch) [96] (Lawrence Collins J); Lindsley v Woodfull [2004] 2 BCLC 131, 140 (Arden LJ); Ultraframe (UK) Ltd v Fielding [2005] EWHC 1638 (Ch) [1344] (Lewison J).

41 This reflects the established view of English law that the existence of a proprietary interest is a matter of property law, not discretion. See Foskett v McKeown [2001] 1 AC 102 (HL) 109 per Lord Browne-Wilkinson. In line with this thinking, English law has adopted an institutional constructive trust in preference to a remedial model.

42 That is, a wrong unconnected to the principal's proprietary interests.

43 Significantly, in FHR European Ventures LLP v Mankarious [2013] EWCA Civ 17, [2014] Ch 1, the Court of Appeal took a different stance. In Mankarious, the defendant was the agent for the claimants in negotiating the purchase of a hotel. The defendant failed to disclose that it had entered into a brokerage agreement with the owner. When the property was sold to the claimants, the defendant received the agreed commission of $€ 10$ million from the owner. The Court of Appeal accepted that the claimants did not, strictly, retain any proprietary interest in the payment to the vendor. Nor was there any proprietary link between the secret commission and the claimants. However, in a practical sense, the brokerage agreement and the secret commission were part of the overall transaction and a constructive trust was imposed over the proceeds. The court renounced the narrow proprietary focus of Sinclair $v$ Versailles and affirmed the rigour of equitable doctrine in respect of a breach of fiduciary duty. For comment on Mankarious, see R Chambers, 'Constructive Trusts and Breach of Fiduciary Duty' [2013] Conv 241; P Devonshire, 'Defining the Boundaries of Personal and Proprietary Relief Against Secret Commissions’ (2013) 24 King’s Law Journal 392.

44 See further Sir Peter Millett, 'Bribes and Secret Commissions' [1993] Restitution Law Review 7, 27-30; M McInnes, 'Interceptive Subtraction, Unjust Enrichment and Wrongs: A Reply to Professor Birks' [2003] CLJ 697, 713. 
employee, belong to the principal. There is no additional need to invoke Reids reasoning in order to characterise the receipt as the principal's property. A proprietary wrong arises in the case of interceptive subtraction of incoming and outgoing funds of the principal. Typically, the former occurs where the agent deducts a secret commission from funds originating from a third party which are intended for the principal. A similar conclusion can be drawn where the defendant deducts a secret commission from the principal's funds before remitting the net proceeds to the intended recipient. ${ }^{45}$ Daraydan Holdings Ltd $v$ Solland International $L t d 46$ is an example of the latter. The claimants remitted funds to the defendants for undertaking the refurbishment of the claimants' properties in London and Qatar. The contracts were arranged by an employee of the claimants. The employee was a fiduciary. The employee required the defendants to pay him a secret commission in respect of these contracts. Without the claimants' knowledge, the contract price was increased by the amount of the bribe and the defendants remitted the illicit gain to the employee. Lawrence Collins J (as he then was) held that the claimants were entitled to a restitutionary remedy because there was a proprietary basis for the claim and the bribes derived directly from the claimants' property. ${ }^{47}$

Conceptually, a distinction can be drawn between subtracting a bribe from the principal's funds and receipt of a bribe directly from the briber as a separate and discrete transaction. On the authority of Lister and Sinclair, where the fiduciary receives a bribe directly from a third party, there is no proprietary base and the claimant is confined to a personal order. However, in terms of outcome and intent, the distinction is less palpable, and it is questionable whether the nature of the relief should be subordinated to the form of the wrongdoing. It is submitted that proprietary relief should theoretically be possible in every purchase and sale transaction where a bribe is received directly from the briber. In both cases a bribe payment can be rationalised as an accretion to, or deduction from, the principal's wealth. This is particularly appropriate given that it is only the fiduciary's deception which prevents the principal from receiving the benefit directly. Where the principal is the vendor, a bribe or secret commission paid by the purchaser can be treated as forming part of the consideration. That is, the purchaser was willing to pay the contract price plus a further sum to acquire the principal's goods or services. Similarly, where the principal is a purchaser, a bribe received by the principal's agent or employee can be treated as a rebate on the purchase price because the vendor was prepared to sell for less than the sum that had apparently been agreed. ${ }^{48}$

This interpretation is not necessarily inconsistent with certain statements in Sinclair. The briber is prepared to pay a premium by way of a bribe to the fiduciary to effect a purchase to, or from, the principal. In both cases the fiduciary failed to press this economic advantage on behalf of his or her principal. The genesis of the wrongful enrichment is therefore an opportunity or right 'properly that of the beneficiary', conferring upon the latter a proprietary interest in the proceeds. Moreover, the additional consideration, or reduced

45 In Lister \& Cov Stubbs (1890) 45 Ch D 1 (CA), it was observed that if the moneys had been paid by the plaintiff to the agent for the payment of goods ordered by the plaintiff, then the agent would have received the funds in a fiduciary capacity and 'they would have come into his hands clothed with a trust' (4 per Stirling J, affirmed by the Court of Appeal). See further C Needham, 'Recovering the Profits of Bribery' (1979) 95 LQR 536.

46 [2004] EWHC 622 (Ch), [2005] Ch 119.

47 Ibid [87].

48 Fawcett $v$ Whithouse (1829) 1 Russ \& M 132, 39 ER 51. To rule otherwise is to adopt the agent's wrongdoing as a basis for denying the principal's beneficial interest in such sums. In Reid it was accepted that the bribe belonged in law to the false fiduciary. The bribe was an inducement to commit a crime. Unlike the present example, the receipt of money in Reid could not be equated to a lawful bargain. 
purchase price, is a pecuniary benefit that falls within the fiduciary's remit to the principal. ${ }^{49}$ As Neuberger MR frankly concedes: 50

In cases where a fiduciary takes for himself an asset which, if he chose to take, he was under a duty to take for the beneficiary, it is easy to see why the asset should be treated as the property of the beneficiary.

Yet the Court of Appeal considered that proprietary restitution is generally unavailable for wrongs where the conduct in question involves receipt of a bribe. ${ }^{51}$ This creates an anomalous exemption, ${ }^{52}$ for the interception of value that is rightfully due to the principal ${ }^{53}$ is surely the exemplar of 'an opportunity or right which was properly that of the beneficiary' 54

Sinclair's analysis relegates the principal to a personal judgment and enables the errant fiduciary to retain consequential gains. In the Court of Appeal it was argued that as a matter of equitable policy a fiduciary should not be allowed to profit from his or her breach. Neuberger MR considered that this should be addressed 'by extending, or adjusting, the rules relating to equitable compensation rather than those relating to proprietary interests' ${ }^{55}$ His Lordship opined that the law relating to equitable compensation was more flexible than the law of property and that an extension of the former would interfere less with the legitimate interests of other creditors. ${ }^{56}$

In response it may be said that, firstly, it is not immediately clear how equitable compensation would serve as a medium for gain-based relief. Secondly, in fulfilling its traditional compensatory function, the context of bribery poses challenges with respect to the measure of loss. Thirdly, assumptions as to the rights of creditors must be assessed against the interests of the betrayed principal. Each will be considered in turn.

\section{Equitable compensation}

\section{(A) Gain-BASED ReLIeF}

With regard to the first point, if the law is developed along the lines suggested by Neuberger MR in Sinclair $v$ Versailles, it would be necessary to fundamentally recast the concept of damages, to encompass the disgorgement of gains. Support for this view is at best sporadic. Occasionally, the gauntlet has been thrown down, urging a broader classification of remedies in place of historical reliance on a 'formulaic division between

49 It has been suggested that a constructive trust is only justified in limited cases where the fiduciary acquires an opportunity he or she was required to pursue on behalf of the principal. It is argued that the improperly acquired property must possess unique significance to the principal or it must have been virtually certain that the principal would have acquired the asset but for the wrongful interception. See P Watts, 'Constructive Trusts and Insolvency' (2009) 3 Journal of Equity 250, 260; P Birks, 'At the Expense of the Claimant: Direct and Indirect Enrichment in English Law' in D Johnston and R Zimmermann (eds), Unjustified Enrichment: Key Issues in Comparative Perspective (CUP 2011) 493. It is submitted that the receipt of a bribe meets even this restrictive standard. The economic return to the principal is invariably the most important aspect of a sale or purchase transaction.

50 [2011] EWCA Civ 347, [2012] Ch 453 [80].

51 That is, in respect of conduct falling outside the formula prescribed by the Court of Appeal. See ibid [88], quoted in text above at $\mathrm{n} 35$.

52 For recent application of this restrictive approach, see Cadogan Petroleum plc v Tolley [2011] EWHC 2286 (Ch); Page v Hewetts Solicitors [2011] EWHC 2449 (Ch); FHR European Ventures LLP v Mankarious [2011] EWHC 2999 (Ch).

53 Increased price as seller or reduced price as purchaser.

54 [2011] EWCA Civ 347, [2012] Ch 453 [88].

55 Ibid [90].

56 Ibid. 
different wrongs' ${ }^{57}$ From this perspective the concept of compensation is not necessarily confined to loss and potentially subsumes gain-based awards. Thus it has been suggested that an account of profits serves a compensatory function in cases where there is no identifiable loss. ${ }^{58}$ In similar vein, the term 'damages' has been expounded as a generic concept on the premise that all monetary relief 59 is a species of damages and therefore awards under this head are not tied exclusively to compensation for loss. ${ }^{60}$

It is, however, questionable whether gain-based relief can be strictly aligned with the orthodox remedy of compensatory damages. At a certain level of abstraction it is, of course, true that all monetary awards provide recompense for wrongs. But, as the focus sharpens, it is apparent that each disposition fulfils a distinct function ${ }^{61}$ of effecting either restitution, disgorgement or compensation. ${ }^{62}$ From this perspective, it is doubtful whether equitable compensation can fulfil the comprehensive profit-stripping function envisaged by Neuberger MR. Nor does it offer any obvious basis for proprietary relief against an asset that has increased in value.

\section{(B) Measure of loss}

Equitable compensation, by definition, compensates for loss. This is usually achieved in one of two ways. In the case of the wrongful paying-away of trust assets in an orthodox trust, the defaulting trustee comes under an immediate duty to reconstitute the trust estate. If specific restitution is not possible then payment must be made to compensate for such loss. ${ }^{63}$ Equitable compensation is not confined to breach of an express trust and finds application more generally in respect of equitable wrongs, particularly in relation to breach of fiduciary duty. ${ }^{64}$ In either case, compensation is intended to restore the injured party to the position which existed before the wrong.

If bribery is rationalised from a compensatory perspective, the determination of loss is problematic. One approach is to adopt the defendant's gain as the measure of the claimant's loss. This reasoning is not without precedent, ${ }^{65}$ but it is counter-intuitive to rationalise a claim to funds from an unlawful source in this manner. A more principled approach, consistent with the economics of commercial bargaining, is to quantify loss by reference to the sum the third-party purchaser or vendor would have paid or accepted, but for the corrupt services of the claimant's agent. ${ }^{66}$ That is, the increased amount the third party would have paid for the claimant's goods or services (the agreed price plus the bribe) or the reduced amount the claimant would have had to pay the third-party vendor (the agreed price minus the bribe). However, this only takes the claim so far. Equitable compensation treats the proceeds of bribery as a notional loss that can be recovered by the claimant. It does not provide a further explanation for stripping the fiduciary of gains deriving from the

57 Devenish Nutrition Ltd v Sanofi-Aventis SA (France) [2008] EWCA Civ 1086 [68] per Arden LJ.

58 WWF-World Wide Fund for Nature v World Wrestling Federation Entertainment Inc [2007] EWCA Civ 286, [2008] 1 WLR 445 [59] (Chadwick LJ). For criticism of this decision, see R Cunnington, 'Changing Conceptions of Compensation' [2007] CLJ 507.

59 With the exception of debt and claims under statute.

60 Stevens v Premium Real Estate Ltd [2009] NZSC 15, [2009] 2 NZLR 384 [98], [99].

61 See Charter plc v City Index Ltd [2007] EWCA Civ 1382, [2008] Ch 313 [64]ff.

62 J Edelman, Gain Based Damages (Hart Publishing 2002) 65ff. See further R Cunnington, 'The Assessment of Gain-Based Damages for Breach of Contract' (2008) 71 MLR 559.

63 Nocton v Lord Ashburton [1914] AC 932 (HL) 952; Target Holdings Ltd v Redferns [1996] 1 AC 421 (HL) 434.

64 Day v Mead [1987] 2 NZLR 443 (CA); Canson Enterprises Ltd v Boughton \& Co (1991) 85 DLR (4th) 129 (SCC).

65 See, for example, Attorney General v Blake [2001] 1 AC 268 (HL) 278.

66 See discussion above. 
original bribe. While the claimant's interest can be adjusted by way of a credit for unpaid consideration or an unpaid rebate, any additional gains made by the fiduciary are incidental to the bribe transaction. Such receipts are a more distant consequence of the wrong and the principal's claim is at best tenuous.

\section{(C) THE INTERESTS OF THE FIDUCIARY'S CREDITORS}

In balancing the appropriate remedial response to bribery, Neuberger MR was conscious of the interests of the fiduciary's creditors. His Lordship considered that such persons required a degree of protection in a contest with the defrauded principal. ${ }^{67}$ Such concerns have frequently been raised by judges and academic commentators in respect of bribery proceedings.

As noted, the Court of Appeal in Lister \& Cov Stubbs defined the relationship between the deceived principal and its fiduciary as one of debtor and creditor. If, on a contrary view, the principal acquired a proprietary interest in the proceeds of bribery, then this would prejudice the fiduciary's creditors in the event of his bankruptcy. For Lindley LJ such a conclusion: 68

would involve consequences which, I confess, startle me. One consequence, of course, would be that, if Stubbs were to become bankrupt, this property acquired by him with the money paid to him by Messrs. Varley would be withdrawn from the mass of his creditors and be handed over bodily to Lister $\approx$ Co. Can that be right?

The interests of the fiduciary's creditors has commonly been cited in support the decision. ${ }^{69}$ In Sinclair v Versailles, Neuberger MR suggested that the Privy Council's advice in Attorney General for Hong Kong $v$ Reid 'may have given insufficient weight to the potentially unfair consequences to the interests of other creditors' ${ }^{70}$

First, and fundamentally, it must be recognised that if the status of bribes is based on such considerations, then the discussion has shifted from principle to policy. This is an undesirable re-arrangement of the argument. ${ }^{71}$ The rights of creditors should be subordinate to the primary decision as to the nature of the wrong and its remedial implications. The impact on creditors is simply a consequence of that decision. ${ }^{72}$ The solvency (or potential insolvency) of the fiduciary should not drive the conclusion. If a

67 See Katingal Pty Ltd v Amor [1999] FCA 317 for discussion of the status of a constructive trust in relation to the rights of creditors in the debtor's insolvency.

68 (1890) 45 Ch D 1 (CA) 15.

69 For example, Re North Australian Territory Company (Archer's Case) [1892] Ch 322 (CA) 338.

70 [2011] EWCA Civ 347, [2012] Ch 453 [83]. While the authorities in this area focus on the interests of unsecured creditors, it should not be overlooked that the interests of some classes of secured creditors may be similarly affected. For example, persons who are unaware of the source of the fiduciary's asset may lend money on an equitable security over the property. See P Watts, 'Bribes and Constructive Trusts' (1994) 110 LQR 178, 179.

71 The argument is exposed to the criticism that has been levied at Attorney General for Hong Kong $v$ Reid, namely that the outcome was policy-driven (in Reid, to reinforce the element of trust and confidence inherent in senior employment relationships).

72 See further Millett ( $\mathrm{n} 44)$ 9-10. 
proprietary claim is sustained, then the asset is simply withdrawn from the insolvent's estate, ${ }^{73}$ with whatever consequences flow from that. ${ }^{74}$ It has aptly been said that: ${ }^{75}$

[T] he entitlement to avoid the rules of pari passu in insolvency is one of the consequences of a finding of a proprietary claim but it is not a reason for such a claim to exist or not . . . the existence or otherwise of proprietary relief should be determined without reference to the interests of the unsecured creditor, since those interests are only valid interests as such if the claimant does not have a proprietary right to those assets.

Secondly, the creditors' claim to priority is unconvincing. A common argument is that the fiduciary's creditors have given value ${ }^{76}$ and should not be postponed to a party who has given nothing and lost nothing. These claims overlook the point discussed above, regarding the principal's transactional loss or unrealised gain. It must also be remembered that creditors have voluntarily assumed the risk of default, whereas the betrayed principal is an involuntary creditor in the fiduciary's insolvency.

More generally, it is submitted that it is an arid exercise to attempt to define priorities between a betrayed trust and an unfulfilled promise of payment to a party who has extended credit. With respect to the latter, Professor Goode comments that 'the debtor's default has swelled his assets at [the creditor's] expense'. ${ }^{77}$ This is of course true. The same may be said of a bribe, subject to the proviso that the bribe is not, at least in a pecuniary sense, acquired at the expense of the principal. However, even the latter qualification can be discounted in light of the earlier suggestion that, depending upon the form of the transaction, a bribe represents either unpaid consideration or an unpaid rebate to the principal.

There will of course be situations where the principal's claim to a constructive trust must be relegated to a personal order ranking pari passu with general creditors. Not uncommonly the proceeds of bribery are used to fund a business venture or an investment. ${ }^{78}$ Its future value may reflect the benefit of dealings with innocent third parties. ${ }^{79}$ In such cases a constructive trust would unjustly enrich the principal at their expense. The fiduciary's assets should not be withdrawn from the general body of creditors when such parties have contributed to its value. ${ }^{80}$

\section{The proprietary argument}

Despite differing views as to the remedial response to bribery, there is consensus that such wrongdoing is an 'evil practice', ${ }^{81}$ which is patently inconsistent with expectations of fiduciary duty. It goes further. Bribery is a criminal offence. ${ }^{82}$ But the gravity of the wrong

73 In other contexts this is uncontroversial. For example, trust assets do not form part of a deceased trustee's estate.

74 A rejoinder is that the role of proprietary relief in enforcing the deterrent principle must be re-examined in the context of insolvency. Arguably, deterrent reasoning is redundant when insolvency supervenes. The apportionment of assets and the preference of one class of claimant over another is a matter of personal irrelevance to the delinquent fiduciary. In this setting the betrayed principal and the fiduciary's general creditors should rank equally. See P Watts, 'Constructive Trusts and Insolvency' (2009) 3 Journal of Equity 250, 280.

75 P McGrath, 'Constructive Trusts: An Analysis of Sinclair v Versailles' [2012] LMCLQ 517 at 521 (emphasis in original).

76 Typically by extending credit for goods and services, or by advancing a loan.

77 R Goode, 'Ownership and Obligation in Commercial Transactions' (1987) 103 LQR 433, 444.

78 Attorney General for Hong Kong v Reid and Lister \& Cov Stubbs are both instances of this.

79 Such parties may, for example, extend credit with or without security over the disputed assets.

80 'Value' in this sense is economically neutral in that it is not confined to gains.

81 Attorney General for Hong Kong v Reid [1994] 1 AC 324 (PC) 330; Daraydan Holdings Ltd v Solland International Ltd [2004] EWHC 622 (Ch), [2005] Ch 119 [1].

82 See the Bribery Act 2010. 
can work to the disadvantage of the betrayed principal. According to Professor Goode, the plaintiff's claim can only be elevated to the status of a proprietary right if the bribe derives from the principal's property or is a benefit the defendant was under a duty to acquire for the principal. ${ }^{83}$ In Sinclair $v$ Versailles this finds expression in the requirement that the money must be beneficially the principal's property, or the benefit acquired by the fiduciary was an opportunity or right belonging to the principal. ${ }^{84}$ Otherwise, the principal is confined to a personal restitutionary order. It is said that this conclusion is justified because the defendant was not engaged to solicit or receive bribes ${ }^{85}$ and was under a negative duty to refrain from such conduct. The fiduciary's actions fell outside the scope of his employment or retainer. The bribe and any gain therefrom would never have accrued to the principal because if the defendant had honoured his obligations he would never have received the bribe in the first place'. 86

Paradoxically, this affords protection from proprietary relief for the more extreme and egregious abuse of office. This runs counter to the development of equity and common law and is the wrong focus for determining relief. It is submitted that the more appropriate question is whether there is proximity between the corrupt acts and the fulfilment of the defendant's services. It is anomalous and unacceptable that the barrier to an affirmative response is the fiduciary's own corruption. There are instances where even the common law has shrugged off the distortion of such reasoning. For example, it was formerly held that a master was not vicariously liable for fraudulent or dishonest acts committed by a servant for his own benefit, because such conduct was outside the scope of his employment. ${ }^{87}$ This reasoning was rejected by the House of Lords in Lloyd $v$ Grace, Smith $\& \mathrm{Co}^{88}$ and denounced in later cases as an affront to common sense. ${ }^{89}$

In discussing Reid, it was seen that equity exposes bribe payments to the full measure of personal and proprietary relief. It is submitted that the Privy Council's advice is unsatisfactory, not in outcome, but in method. This is a teleological judgment directed to a remedial outcome that reflects the court's abhorrence of certain conduct. ${ }^{90}$ The maxim 'equity regards as done that which ought to be done', which is central to the decision, is a sparse rationale for the shift from personal to proprietary obligation. It is not an objective in itself, but a normative statement without an obvious outcome. It simply begs the question as to the appropriate remedy. Thus, it is equally tenable to speak of an account of profits as it is to postulate a trust relationship. Moreover, as a technique, the equitable maxim does not fit comfortably, or effectively, with the context. The maxim more appropriately supports a primary decision founded on substantive principles and pre-existing rights. It is essentially

83 R Goode, 'Ownership and Obligation in Commercial Transactions' (1987) 103 LQR 433, 443-44.

84 [2011] EWCA Civ 347, [2012] Ch 453 [88]. At that point, the claimant can elect whether to assert a proprietary claim. If bribe proceeds have been used to acquire property, the claimant may or may not wish to claim the asset in specie. If the fiduciary acquired a diminishing asset, the claimant may prefer to assert a personal claim, subject to an equitable lien or charge over the property as security for any unpaid balance. See Foskett $v$ McKeown [2001] 1 AC 102 (HL) 130.

85 [2011] EWCA Civ 347, [2012] Ch 453 at [80]. See further R Goode, 'Property and Unjust Enrichment' in A A Burrows (ed) Essays on the Law of Restitution (Clarendon Press, 1991) 215, 230-31.

86 R Goode, 'Proprietary Liability for Secret Profits - A Reply' (2011) 127 LQR 493, 494.

87 British Mutual Banking Co Ltd v Charnwood Forest Railway Co (1887) 18 QBD 714 (CA); Cheshire v Bailey [1905] 1 KB 237 (CA); Ruben v Great Fingall Consolidated [1906] AC 439 (HL).

88 [1912] AC 716 (HL).

89 Perhaps most notably in the landmark case of Morris v CW Martin \& Sons Ltd [1966] 1 QB 716 (CA) at 735-36 (Diplock LJ) and 738-740 (Salmon LJ).

90 The purposive nature of this decision is captured by Lord Templeman's comment that the fiduciary is not allowed by any means to make a profit out of the breach of duty' ([1994] 1 AC 324, 332). 
a secondary rule designed to recognise rather than create rights. Most commonly it is applied in consensual transactions to enforce an informal agreement to transfer property or create a legal interest. ${ }^{91}$ In this setting, the maxim supports an obligation to transfer property. In contrast, where the fiduciary receives a bribe directly from the briber, there is no transactional link between the bribe and the fiduciary's duty to his or her principal. Accordingly there is no identifiable res to which the maxim can apply. ${ }^{92}$

The equitable maxim which insists on due performance is reflected in the 'good person' fiction which is invoked to reverse the effects of wrongdoing by a fiduciary. ${ }^{93}$ As Professor Finn (as he then was) expresses the point: ${ }^{94}$

The fiduciary is normally not permitted to say that the benefit derived was derived other than for his beneficiary, even though this is transparently contrary to his real intentions when deriving it.

This is affirmed in evidential presumptions that reinforce the strict standards of fiduciary duty. For example, the rule in Re Hallett's Estate ${ }^{95}$ that in the discharge of a fiduciary's duties it is presumed that, whenever an act can be done rightfully, the fiduciary is not allowed to maintain against his principal that he has done so wrongly. ${ }^{96}$ Similar principles apply in assessing loss. For example, where a trustee mismanages trust assets, the court may presume that the principal was deprived of the highest economic return for the property. ${ }^{97}$

The good person fiction and related evidential rules impose what is essentially an irrebuttable presumption of probity on conduct that is clearly tainted. In this regard, Lord Templeman was emphatic in stating: 98

[E]quity insists on treating him as having acted in accordance with his duty; he will not be allowed to say that he preferred his own interest to that of his principal. He must not obtain a profit for himself out of his fiduciary position. If he has done so, equity insists on treating him as having obtained it for his principal; he will not be allowed to say that he obtained it for himself. He must not accept a bribe. If he has done so, equity insists on treating it as a legitimate payment intended for the benefit of his principal; he will not be allowed to say that it was a bribe.

This, then, becomes the substituted performance of the fiduciary's overriding duty to act selflessly in the interests of his principal. ${ }^{99}$ Manifestly, the putative good faith performance of bad faith actions does not respond to the argument that proprietary restitution is only justified where the claim has a proprietary base. It simply assumes - or more adventurously, creates - the premise ${ }^{100}$ which is so critical to restitutionary reasoning. The two positions do not connect. The internal logic of each is at times compelling, but these are parallel arguments, without an obvious point of intersection.

91 Walsh v Lonsdale (1882) 21 Ch D 9 (CA).

92 P Birks, 'Obligations and Property in Equity: Lister v Stubbs in the Limelight' [1993] LMCLQ 30, 32.

93 For recent discussion, see D Hayton, 'No Proprietary Liability for Bribes and Other Secret Profits?' (2011) 25 Trust Law International 3.

94 P D Finn (ed), Essays on Restitution (Lawbook Co 1990) 221.

95 (1879) 13 Ch D 696 (CA).

96 Ibid 729 per Sir George Jessel MR.

97 Guerin v The Queen [1984] 2 SCR 335.

98 [1994] 1 AC 324 (PC) at 337, citing Millett (n 44) 20.

99 D Hayton, 'No Proprietary Liability for Bribes and Other Secret Profits?' (2011) 25 Trust Law International $3,4,14$.

100 As compendiously expressed in Reid: 'As soon as the bribe was received . . . the false fiduciary held the bribe on a constructive trust' ([1994] 1 AC 324, 331). 
With respect to the equitable position, it is preferable to acknowledge an objective wrong than to assert a fictitious right. The latter is an unconvincing foundation for defining substantive proprietary interests. It is submitted that the remedial implications of bribery should be absorbed within equity's general governance of fiduciary wrongs. On orthodox reasoning, the receipt of a bribe is a breach of the profit rule. More expansively, such misconduct is, or should be, encompassed by an obligation to disgorge unauthorised benefits, including gains derived from the wrongful exploitation of a fiduciary position. Australian jurisprudence in particular has embraced this approach, adopting the constructive trust as a vehicle for reversing gains where a fiduciary has misused his or her position for personal advantage. ${ }^{101}$ As Mason J observed in Hospital Products Ltd $v$ United States Surgical Corporation: 102

A fiduciary is liable to account for a profit or benefit if it was obtained (1) in circumstances where there was a conflict, or possible conflict of interest and duty, or (2) by reason of the fiduciary position or by reason of the fiduciary taking advantage of opportunity or knowledge which he derived in consequence of his occupation of the fiduciary position... Any profit or benefit obtained by a fiduciary in either of the two situations already described is held by him as a constructive trustee . . . Neither principle nor authority provide any support for the proposition that relief by way of constructive trust is available only in the case where a profit or benefit obtained by the fiduciary was one which it was an incident of his duty to obtain for the person to whom he owed the fiduciary duty ... What is important is that the advantage has accrued to him in breach of his fiduciary duty or by his misuse of his fiduciary position.

This approach addresses the mischief of fiduciary wrongs and avoids narrow qualifications directed to whether the interest was acquired from, or acquired on behalf of, the principal, or whether the defendant received, subtracted or intercepted the illicit gain.

\section{Conclusion}

The ability of the betrayed principal to assert a proprietary claim against a bribe or its proceeds in the hands of the errant fiduciary is dependent on the vagaries of the particular bribe arrangement. If the bribe has been subtracted directly from the principal's property or intercepted from funds destined for the principal, there is a sufficient base for a proprietary restitutionary response. Reid indicates that such actions would similarly attract proprietary relief in equity, typically by means of a constructive trust. However, on the authority of Lister and Sinclair, where the fiduciary receives a bribe directly from the briber, there is no proprietary base and the claimant is confined to a personal order. This is unduly restrictive. It has been argued that there is a sufficient proprietary nexus because the bribe represents withheld consideration or an unpaid rebate. It has also been submitted that a proprietary response is consistent with Sinclair's concession in respect of benefits that the fiduciary was under a duty to obtain for the principal.

A corollary of the Lister-Sinclair model is that the faithless fiduciary may be able to retain gains deriving from the bribe. Neuberger MR's suggestion that this can be redressed by equitable compensation is problematic, not least because of the difficulty of reconciling disgorgement with the traditional compensatory function of damages.

101 Contrast with Sinclair's restrictive view that an asset or money acquired in breach of a trustee's duties to the beneficiary which 'could not have been obtained if he had not enjoyed his fiduciary status' will not necessarily be held on trust for the principal ([2011] EWCA Civ 347, [2012] Ch 453 [89]).

102 (1984) 156 CLR 41, 107-08. See also Keith Henry \& Co Pty Ltd v Stuart Walker \& Co Pty Ltd (1958) 100 CLR 342, 350; Chan v Zacharia (1984) 154 CLR 178, 198-99. 
The concern expressed in Lister and Sinclair, that proprietary relief will prejudice the interests of the fiduciary's general creditors, is an argument of policy, not principle. In espousing the creditors' position, there is a tendency to marginalise the principal's status. For example, while creditors have given value, this must be weighed against the principal's transactional loss. Again, it is often overlooked that the betrayed principal is an involuntary creditor, whereas third parties have voluntarily assumed the risk of default.

Reid's attempts to overcome the absence of a transactional link where a bribe is received directly from a third party is unconvincing. The Privy Council's doctrinaire application of equitable principle does not respond to the objection that proprietary restitution requires a proprietary base. The restitutionary and equitable arguments simply reflect different philosophical positions and the protagonists are shadow-boxing on different planes. As matters stand, the status of bribes is governed by narrow, often accidental, factual variations. The nature and taxonomy of the wrong has attracted vigorous debate. A pragmatic unitary response is needed. It has been suggested that the remedial consequences of bribery should be absorbed within the general governance of equitable wrongs, ${ }^{103}$ where proprietary relief can appropriately be granted to reverse enrichments from the corrupt exploitation of a fiduciary's position. 
